\section{Antispasmodic effect of Jatropha gossypiifolia is mediated through dual blockade of muscarinic receptors and $\mathrm{Ca}^{2+}$ channels}

\author{
Selma do N. Silva, " Iracelle C. Abreu, Sônia Maria de F. Freire, \\ Maria do Socorro de S. Cartágenes, Rachel M. Ribeiro, Ahirlan \\ S. de Castro, Antônio C. R. Borges, Marilene O. da R. Borges
}

Laboratório de Pesquisa e Pós-graduação em Farmacologia, Departamento de Ciências Fisiológicas, Centro de Ciências Biológicas e da Saúde, Universidade Federal do Maranhão, Brazil.

\begin{abstract}
The antispasmodic activity of Jatropha gossypiifolia L., Euphorbiaceae, aerial parts was investigated in rodents using the mouse intestinal transit model and acetylcholine ( $\mathrm{ACh}, 10^{-9}$ to $\left.10^{-4} \mathrm{M}\right)$ and calcium $\left(\mathrm{CaCl}_{2}, 10^{-4}\right.$ to $\left.10^{-1} \mathrm{M}\right)$-induced contractions of isolated rat jejunum. Similar to atropine $(1 \mathrm{mg} / \mathrm{kg})$, oral doses of ethanolic extract (EE) of J. gossypiifolia $(500,1000$ and $2000 \mathrm{mg} / \mathrm{kg}$ ) produced a decrease in intestinal transit (37.6 to $57.1 \%$ ) when compared with control. The ACh-induced contraction in the jejunum was inhibited by EE $(0.5,1.0$ and $2.0 \mathrm{mg}$ / $\mathrm{mL})$, chloroformic $(\mathrm{CF})$ and aqueous fractions $(0.1$ and $0.5 \mathrm{mg} / \mathrm{mL})$ and methanolic subfraction $(0.05$ and $0.25 \mathrm{mg} / \mathrm{mL})$, suggesting an antimuscarinic mechanism. $\mathrm{CaCl}_{2}$ - induced responses in jejunum were also attenuated in the presence of CF $(0.05$ and $0.1 \mathrm{mg} / \mathrm{mL}$ ) implying a direct interference of CF with the influx of calcium ions in the cells. Only the organic fraction of the extract had a calcium-antagonist effect, whereas both chloroformic and aqueous fractions had anticholinergic effect. These results suggest that the antispasmodic effect of $J$. gossypiifolia may be due a combination of anticholinergic and calcium antagonist mechanisms.
\end{abstract}

Revista Brasileira de Farmacognosia Brazilian Journal of Pharmacognosy 21(4): 715-720, Jul./Aug. 2011

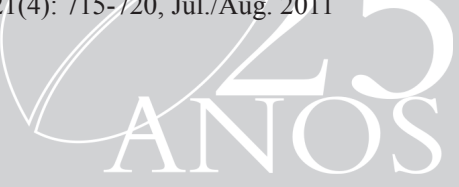

\section{Article}

Received 29 Sep 2010

Accepted 24 Jan 2011

Available online $29 \mathrm{Jul} 2011$

Keywords:

antimuscarinic mechanism,

antispasmodic

calcium channel antagonist Jatropha gossypiifolia

ISSN 0102-695X doi: $10.1590 / \mathrm{S} 0102-695 \mathrm{X} 2011005000130$

\section{Introduction}

Jatropha gossypiifolia L., Euphorbiaceae, is a small shrub, which grows to a height of about 1.5 $\mathrm{m}$ and is found in several areas of the world, most commonly in tropical regions (Joly, 1979). The species of the Jatropha genus are popularly known in Brazil as 'pião-roxo', 'jalapão', 'raiz-do-téu', 'erva-purgante', 'mamoninha' and 'batata-do-téu'. Several Jatropha species have been used in the traditional system of medicine as anti-rheumatic, wound healing (Corrêa, 1984), antidiarrhoeal, diuretic, antiulcerogenic (Duke, 1985) and hypotensive agents (Villar et al., 1986). Some of these traditional uses appear to be supported by data provided by pharmacological studies. For example, the methanol extract of Jatropha curcas L. was shown to possess activity against castor oil induced diarrhea and to reduce gastrointestinal motility after charcoal meal administration in albino mice (Mujumdar et al., 2000). In addition, the ethanolic extract of J. gossypiifolia can elicit hypotension in conscious normotensive rats when given by oral route, and has vasorelaxant activity in rat mesenteric rings precontracted with norepinephrine
(NE) or $\mathrm{Ca}^{2+}$ (Abreu et al., 2003). Furthermore, Jatrophone, a naturally occurring diterpene isolated from the rhizome of the medicinal plant Jatropha elliptica (Pohl.) Müll. Arg, inhibited contraction in vascular and extra-vascular smooth muscle, as well as cardiac muscle preparations (Calixto \& Sant'ana, 1987; Calixto \& Sant'ana, 1990; Duarte et al., 1992; Silva et al., 1995).

The phytochemical investigation of $J$. gossypiifolia has previously shown the presence of organic acids, alkaloids, diterpenes, steroids, flavonoids, lignans, and tannin, among many other constituents (Adesina, 1982; Coe \& Anderson, 1996; Das \& Anjani, 1999; Ogbobe \& Akano, 1993; Subramanian et al., 1971). Meanwhile, acute toxicological studies on the ethanol extract of the aerial parts of $J$. gossypiifolia in rats indicate a low acute oral toxicity (Mariz et al., 2008; Mariz et al., 2006).

The aim of the present study was to investigate the effect of $J$. gossypiifolia aerial parts on intestinal transit velocity and on isolated rat jejunum, in order to determine the possible mechanism of action of this plant as antidiarrhoeal agent. 


\section{Materials and Methods}

\section{Plant material}

The aerial parts (stems and leaves) of plant were collected from the urban area of São Luís, MA, Brazil, in August 2000. This material was identified as Jatropha gossypiifolia L., Euphorbiaceae, and a voucher specimen (No 1006) was deposited in the Atico Seabra Herbarium of the Universidade Federal do Maranhão.

\section{Preparation of crude extract and fractionation}

Dried and powdered stems and leaves (200 g) were extracted with $95 \% \mathrm{EtOH}$. The resulting ethanolic extract (EE) was filtered and evaporated to dryness using a vacuum rotary evaporator (yield: $7.6 \%$ ). The EE was fractionated by simple partition, with chloroform and water (2:1), to obtain the chloroformic (CF) and aqueous (AF) fractions with a yield of 29 and $71 \%$, respectively. The CF was then separated in subfractions by liquid column chromatography with solvents of increasing polarity: hexane (HSf), dichloromethane (DSf), ethyl acetate (EtSf) and methanol (MSf). The yield of the subfractions were 3.5, 3.8, 40.3 and 50.3\%, respectively.

\section{Animals}

Swiss albino mice (20-25 g) and Wistar albino rats (160-200 g) of either sex from the Universidade Federal de São Paulo, Brazil were used. They were kept under standard environmental conditions with food and water ad libitum. All procedures described in the present study were approved by the Animal Research Ethics Committee of the State University of Maranhão, Brazil (Protocol number 05/2005).

\section{Small intestinal transit}

Swiss albino mice were fasted for $6 \mathrm{~h}$ prior to the experiments, but were allowed free access to water. They were divided into five groups of 6-10 mice each. The first group, which received saline $(10 \mathrm{~mL} /$ $\mathrm{kg}$, p.o.) by gavage, served as control. The second group received atropine sulfate $(1.0 \mathrm{mg} / \mathrm{kg}$, p.o. $)$ as the standard drug, while the last three groups received EE $(0.5,1.0$ or $2.0 \mathrm{~g} / \mathrm{kg}$, p.o., respectively). Sixty minutes after the treatment, these mice were given a charcoal meal (a 10\% charcoal suspension in 5\% gum arabic solution, $0.1 \mathrm{~mL} / 10 \mathrm{~g}$ ), orally. All animals were sacrificed $15 \mathrm{~min}$ later and the small intestine was rapidly dissected out and placed on a clean surface. The intestine was carefully inspected and the distance traversed by the charcoal meal plug from the pylorus to the cecum was measured. The length of the whole small intestine was also measured. The distance traveled by the charcoal plug from pylorus to cecum was expressed as a percentage of the total length of the small intestine (Rao et al., 1997).

\section{Isolated rat jejunum tissue preparations}

Cumulative dose response curves for acetylcholine $(\mathrm{ACh})$ or calcium $\left(\mathrm{Ca}^{2+}\right)$ were determined in the absence (control) or presence of extracts (Van Rossum, 1963). Segments of jejunum (2 cm long) were suspended in a $20 \mathrm{~mL}$ organ bath containing Tyrode's solution aerated with $95 \% \mathrm{O}_{2}, 5 \% \mathrm{CO}_{2}(\mathrm{pH} 7.4)$ and maintained at $37{ }^{\circ} \mathrm{C}$. The preparations were set up under a tension of $1 \mathrm{~g}$ and responses were recorded on a smoked Kymograph paper through an isotonic frontal writing lever (magnification x 6). After $30 \mathrm{~min}$ equilibration period, cumulative concentration-response curves for ACh (10-9 to 10-4 M) were recorded in the absence and presence of the $\operatorname{EE}(0.5,1.0$ and $2.0 \mathrm{mg} /$ $\mathrm{mL}), \operatorname{AF}(0.1$ and $0.5 \mathrm{mg} / \mathrm{mL}), \mathrm{CF}(0.1$ and $0.5 \mathrm{mg} / \mathrm{mL})$ and $\operatorname{MSf}(0.05$ and $0.25 \mathrm{mg} / \mathrm{mL})$.

In another set of experiments, the role of the calcium was evaluated by depolarizing the tissue $(\mathrm{KCl}$, $70 \mathrm{mM}$ ) in calcium-free solution. After the stabilization during $30 \mathrm{~min}$ in normal Tyrode's solution, the external calcium was eliminated with depolarizing Tyrode's solution ( $\mathrm{KCl}, 70 \mathrm{mM}$; $\mathrm{Ca}^{2+}$-free). A cumulative concentration-response curves of $\mathrm{Ca} 2+$ were obtained by cumulatively adding $\mathrm{CaCl}_{2}\left(10^{-4}\right.$ to $\left.10^{-1} \mathrm{M}\right)$ in the absence and presence of $\mathrm{CF}^{2}(0.1$ and $0.5 \mathrm{mg} / \mathrm{mL})$, which were added to the bath $10 \mathrm{~min}$ before addition of $\mathrm{Ca}^{2+}$. This curve was compared with those obtained in the absence of $\mathrm{CF}$ and the results were expressed as percentages of the maximal response to $\mathrm{CaCl}_{2}$ alone.

\section{Drugs and solutions}

Tyrode's solution was composed of (mM): $\mathrm{NaCl}, 135.0 ; \mathrm{KCl}, 5.0 ; \mathrm{MgCl} 2.6 \mathrm{H}_{2} \mathrm{O}, 1.0 ; \mathrm{NaH}_{2} \mathrm{PO}_{4}$, 1.0; $\mathrm{NaHCO}_{3}, 15.0 ; \mathrm{CaCl}_{2} .2 \mathrm{H}_{2} \mathrm{O}, 2.0$ and $\mathrm{C}_{6} \mathrm{H}_{12} \mathrm{O}_{6}$ (glucose), 11.1. The composition of the depolarized Tyrode's solution was $(\mathrm{mM}): \mathrm{NaCl}, 18.88 ; \mathrm{KCl}$, 70.09; $\mathrm{MgCl}_{2} .6 \mathrm{H}_{2} \mathrm{O}, 0.5 ; \mathrm{NaH}_{2} \mathrm{PO}_{4}, 0.5 ; \mathrm{NaHCO}_{3}, 7.5$; $\mathrm{CaCl}_{2} .2 \mathrm{H}_{2} \mathrm{O}, 1.0$ and $\mathrm{C}_{6} \mathrm{H}_{12} \mathrm{O}_{6}$ (glucose), 2.78.

The following drugs were used in the experiments, acetylcholine chloride (Merck), atropine sulfate (Sigma), charcoal and gum arabic.

\section{Statistical analysis}

All data were expressed as mean \pm SEM. The results were expressed as mean \pm SD of six determinations. Statistical evaluation was performed 
using the Student's t-test or one-way analysis of variance (ANOVA). A probability value of $p<0.05$ was considered to be significant (Graph Pad version 5.0).

\section{Results and Discussion}

The objective of this work was to study the action of Jatropha gossypiifolia L. on intestinal transit velocity and on contractile activity induced by $\mathrm{Ca}^{2+}$ and $\mathrm{ACh}$ in isolated rat jejunum, to seek scientific evidence for the beneficial use of this plant in gastrointestinal disorders.

Current therapy for some of these disturbances is directed towards the inhibition of smooth muscle contraction. Antagonists of muscarinic receptors are used in the control of such conditions. Pretreatment of mice with the ethanolic extract (EE) of $J$. gossypiifolia at doses of 500,1000 and $2000 \mathrm{mg} / \mathrm{kg}$ and atropine (1 $\mathrm{mg} / \mathrm{kg}$ ), given by oral route, $60 \mathrm{mim}$ before charcoal meal administration, caused a reduction of 37.6, 52.7, 57.1 and $39.5 \%$, respectively, in the velocity of small intestinal transit, when compared with the effect produced by the saline control (49.6 \pm 1.2$)$, as shown in Table 1.

Table 1. Effect of the EE of Jatropha gossypiifolia L. on intestinal transit in mice.

\begin{tabular}{lccc}
\hline \multicolumn{1}{c}{ Group } & Dose $(\mathrm{mg} / \mathrm{kg})$ & $\begin{array}{c}\text { Distance } \\
\text { travelled (\%) }\end{array}$ & $\begin{array}{c}\text { Inhibition of } \\
\text { motility (\%) }\end{array}$ \\
\hline Control (saline) & ------ & $49.6 \pm 1.2$ & ------ \\
Atropine & 1.0 & $30.0 \pm 2.8$ & $39.5^{*}$ \\
$\quad 500$ & $30.9 \pm 4.7$ & $37.6^{*}$ \\
$\quad$ Ethanolic & 1000 & $23.5 \pm 3.3$ & $52.7^{*}$ \\
Extract (EE) & 2000 & $21.3 \pm 2.4$ & $57.1^{*}$ \\
\hline
\end{tabular}

$* p<0.05$ vs. control. Mean \pm SEM ( $\mathrm{n}=6-10)$. Student's $t$-test.

Muscarinic receptors of the $\mathrm{M}_{3}$ subtype are present on smooth muscle where they are responsible for initiating contraction in response to agonist binding (Weiser et al., 1997). Agonist like acetylcholine (ACh) is a neurotransmitter at post-ganglionic parasympatic neurons that innervate the digestive tract and induce contraction by stimulating their respective receptor $\left(\mathrm{M}_{3}\right)$. After binding with $\mathrm{ACh}, \mathrm{M}_{3}$ receptors activate phospholipase $\mathrm{C}$ (PLC) and enhances inositol triphosphate $\left(\mathrm{IP}_{3}\right)$ production followed by promotion of $\mathrm{Ca}^{2+}$ release from intracellular $\mathrm{Ca}^{2+}$ pools (sarcoplasmic reticulum). Consequently intracellular calcium level is increased through receptor operated calcium channel (ROC). This $\mathrm{Ca}^{2+}$ release activates VOC that leads to influx of $\mathrm{Ca}^{2+}$ from extracellular fluid (Caulfield, 1993; Eglen et al., 1996). We used isolated rat jejunum to investigate whether the reduction in intestinal motility caused by EE was mediated through inhibition of some element of the $\mathrm{M}_{3} / \mathrm{PLC} / \mathrm{IP}_{3}$ system, with consequent interference in the availability of intracellular $\mathrm{Ca}^{2+}$. This preparation responded to the addition of $\mathrm{ACh}\left(10^{-9}\right.$ to $10^{-4} \mathrm{M}$ ) with contractions of increasing magnitude in proportion to the drug concentration, with a pD2 value $\left(\mathrm{pD}_{2}=-\log \mathrm{EC} 50\right.$, negative logarithm of molar concentration of agonist that caused half maximal response) of $6.91 \pm 0.03$. In the presence of $\mathrm{EE}$, at concentrations of $0.5,1.0$ and $2.0 \mathrm{mg} / \mathrm{mL}$, the $\mathrm{pD}_{2}$ value was altered in a concentration dependent manner to $6.14 \pm 0.12,5.63 \pm 0.13$ and $4.85 \pm 0.11$, respectively. The maximal response, to ACh was reduced in 12.6, 29.9 and $49.3 \%$ in the presence of the EE at $0.5,1.0$ and $2.0 \mathrm{mg} / \mathrm{mL}$, respectively (Figure 1), suggesting the presence of one or more antispasmodic component. The EE suppressed responses to ACh through both competitive and noncompetitive mechanisms in the jejunum.

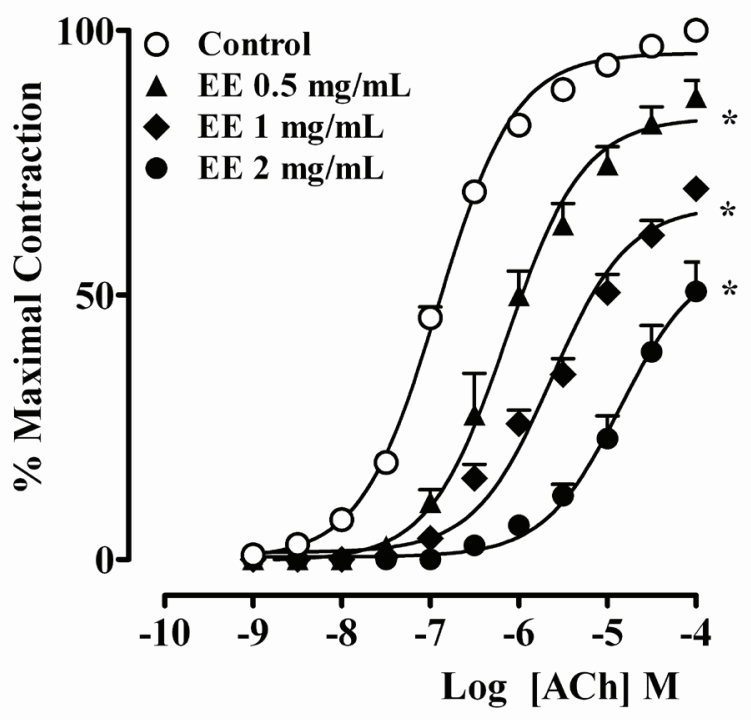

Figure 1. Cumulative concentration-response curves of ACh in isolated rat jejunum in the absence $(\mathbf{O})$ and presence of $\mathrm{EE}$ of Jatropha gossypiifolia L. $0.5 \mathrm{mg} / \mathrm{mL}(\boldsymbol{\Delta}), 1.0 \mathrm{mg} / \mathrm{mL}(\bullet)$ and $2.0 \mathrm{mg} / \mathrm{mL}(\bullet)$. The points are mean and the vertical bars show the S.E.M. $(\mathrm{n}=5) .{ }^{*} p<0.05$ vs. control, ANOVA.

To examine the behavior of the active principles present in $\mathrm{EE}$, the $\mathrm{AF}$ and $\mathrm{CF}$ also were studied in isolated rat jejunum preparations with contractions induced by ACh. The addition of the AF at a concentration of $0.5 \mathrm{mg} /$ $\mathrm{mL}$ displaced the cumulative concentration-response curve of ACh to the right, in a parallel manner, by a factor of 3 (Figure 2), indicating competitive antagonism of muscarinic receptors. On the other hand, the $\mathrm{CF}$ at concentrations of 0.1 and $0.5 \mathrm{mg} / \mathrm{mL}$, displaced the cumulative concentrationresponse curves of $\mathrm{ACh}$ to the right, in a concentrationdependent but non parallel manner; furthermore, the $\mathrm{CF}$ reduced the maximal response to ACh by 14.7 and $37.5 \%$, respectively, when compared with control, suggesting a possible muscarinic anticholinergic activity and the 
presence of another antispasmodic constituent (Figure 3a).

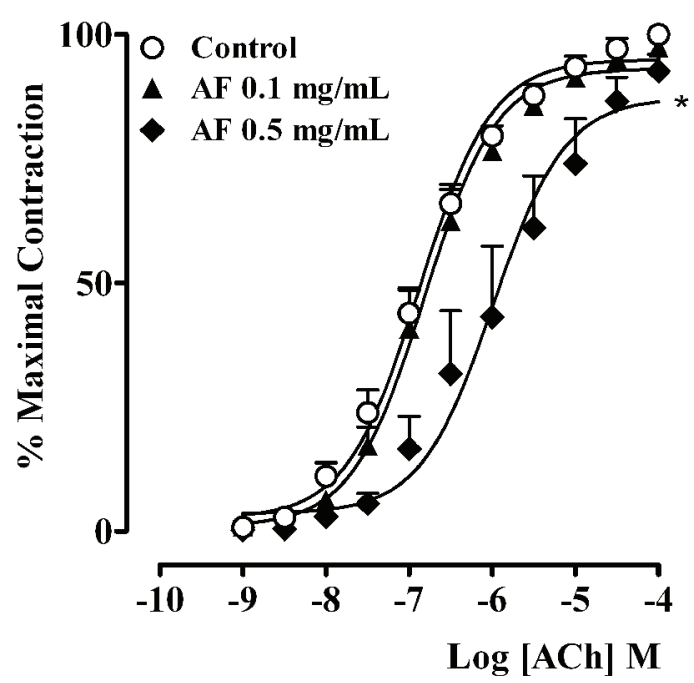

Figure 2. Cumulative concentration-response curves of $\mathrm{ACh}$ in isolated rat jejunum in the absence $(\mathbf{O})$ and presence of aqueous fraction (AF) of Jatropha gossypiifolia L. $0.1 \mathrm{mg} / \mathrm{mL}(\boldsymbol{\Delta})$ and $0.5 \mathrm{mg} / \mathrm{mL}(\bullet)$. The points are mean and the vertical bars show the S.E.M. $(\mathrm{n}=5) .{ }^{*} p<0.05$ vs. control, ANOVA.

(a)

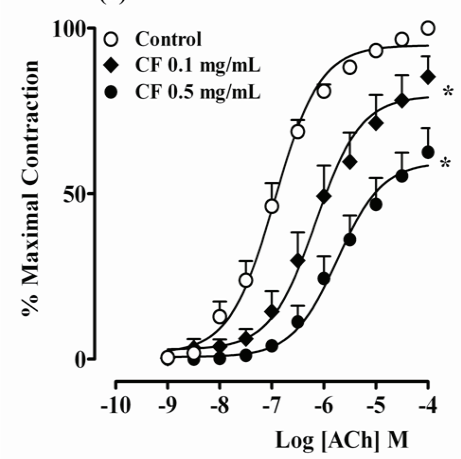

(b)

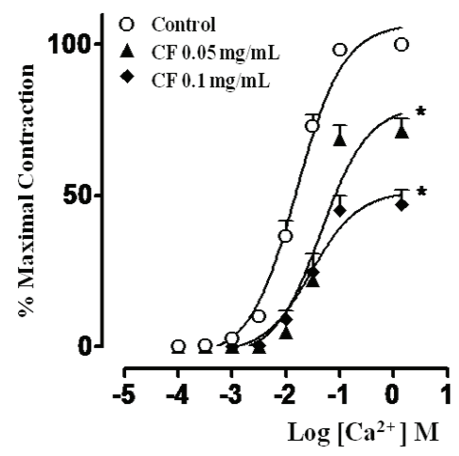

Figure 3. Cumulative concentration-response curves of ACh (a. acethylcoline) and $\mathrm{Ca}^{2+}$ (b. calcium) in isolated rat jejunum in the absence (O) and presence of chloroformic fraction (CF) of Jatropha gossypiifolia L. $0.05 \mathrm{mg} / \mathrm{mL}(\boldsymbol{\Delta}), 0.1 \mathrm{mg} / \mathrm{mL}(\bullet)$ and $0.5 \mathrm{mg} / \mathrm{mL}(\bullet)$. The points are mean and the vertical bars show the S.E.M. (n=5). ${ }^{*} p<0.05$ vs. control, ANOVA.
The contraction of smooth muscle preparations, including rat jejunum, is dependent upon an increase in cytoplasmic free $\left[\mathrm{Ca}^{2+}\right]$, which activates the contractile elements. The contraction of smooth muscle induced by high $\mathrm{K}^{+}$is dependent, in turn, upon the entry of $\mathrm{Ca}^{2+}$ into the cells through voltage activated ion channels, while inhibition of high $\mathrm{K}^{+}$-induced contraction results from the prevention of $\mathrm{Ca}^{2+}$ entry through these channels (Al-Zuhair et al., 1996; Bolton, 1979), a characteristic of calcium channel blockers (CCB). It was observed previously that the antispasmodic constituents present in various medicinal plants mediate their effect usually through a CCB action (Ghayur et al., 2006; Gilani et al., 2006; Shah et al., 2010). In order to elucidate the possible mechanism of the antispasmodic effect of CF, we investigated the interference of CF with voltage operated calcium channels. To this end, the jejunum was first treated with depolarized Tyrode's solution (70 $\mathrm{mM} \mathrm{KCl}$ ). The tissue was then contracted with increasing concentrations of calcium chloride $\left(\mathrm{CaCl}_{2}-10^{-4}\right.$ to $\left.10^{-1} \mathrm{M}\right)$, with a $\mathrm{pD}_{2}$ value of $1.80 \pm 0.05$. Under such conditions the contraction of smooth muscle is dependent upon influx of calcium through voltage-dependent ion channels. In the presence of $\mathrm{CF}$, at 0.05 and $0.1 \mathrm{mg} / \mathrm{mL}$, the $\mathrm{pD}_{2}$ values were lowered to $1.34 \pm 0.02$ and $1.53 \pm 0.08$, respectively. The addition of the $\mathrm{CF}$ at 0.05 and $0.1 \mathrm{mg} / \mathrm{mL}$, displaced the cumulative concentration-response curves of $\mathrm{CaCl}_{2}$ to the right, in a non-parallel manner and the maximal response was reduced, in a concentration-dependent manner, by 28.7 and $52.9 \%$ in the presence of the CF at 0.05 and $0.1 \mathrm{mg} / \mathrm{mL}$, respectively (Figure $3 \mathrm{~b}$ ), suggesting that the antispasmodic effect is possibly mediated through the inhibition of $\mathrm{Ca}^{2+}$ influx probably through voltagedependent ion channels. The cholinomimetic constituent(s) of the plant was (were) concentrated in the aqueous fraction, while the organic fraction (chloroformic) was found to be rich in calcium channel antagonist activity and with cholinomimetic constituents, which means that the cholinomimetic compound(s) is (are) soluble in both polar and nonpolar solvents, or equally, that this fraction contains active principles with distinct polarities.

In the presence of the methanol subfraction (MSf) at 0.05 and $0.25 \mathrm{mg} / \mathrm{mL}$ the curve for ACh was displaced to the right, in a concentration- dependent manner, by a factor of 1.92 and 5.16, while the maximum ACh-induced contraction was reduced by $14.7,37.5,29.7$ and $28.7 \%$, respectively (Figure 4), suggesting both competitive and non-competitive antagonism.

In conclusion, the results presented here show that the EE and fractions of Jatropha gossypiifolia L. inhibit the effect of $\mathrm{ACh}$ on intestinal smooth muscle by both competitive and non competitive mechanisms, suggesting a possible muscarinic anticholinergic activity. On the other hand, the $\mathrm{CF}$ altered $\mathrm{Ca}^{2}+$-induced contraction, suggesting that $J$. gossypiifolia contains substances that can alter the calcium mobilization into cells in this preparation, and 
which probably correspond to the component(s) responsible for the non competitive effect obtained in tests using ACh. These properties may explain the use of the genus Jatropha as an antidiarrhoeal agent in traditional medicine. However, studies must be conducted in the future, for a better understanding of the involucrated mechanisms and the identification of the active compounds responsible for the pharmacological observed effects.

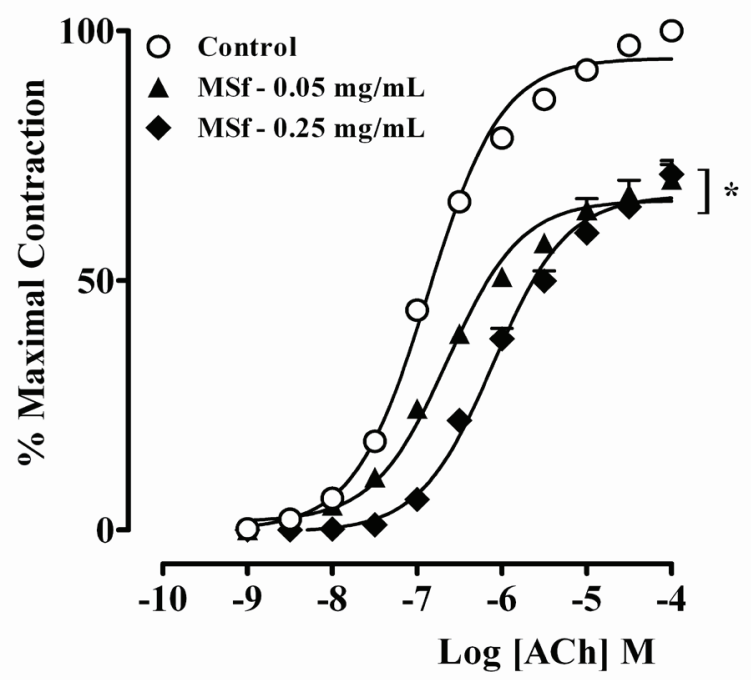

Figure 4. Cumulative concentration-response curves of $\mathrm{ACh}$ in isolated rat jejunum in the absence $(\mathbf{O})$ and presence of methanol fraction (MSf) of Jatropha gossypiifolia L. $0.05 \mathrm{mg} / \mathrm{mL}(\boldsymbol{\Delta})$ and $0.25 \mathrm{mg} / \mathrm{mL}(\bullet)$. The points are mean and the vertical bars show the S.E.M. (n=5). ${ }^{*} p<0.05$ vs. control, ANOVA.

\section{Acknowledgment}

This work was supported by grants and fellowships from Federal University of Maranhão and Brazilian National Research Council.

\section{References}

Abreu IC, Marinho AS, Paes AM, Freire SM, Olea, RS, Borges MO, Borges AC 2003. Hypotensive and vasorelaxant effects of ethanolic extract from Jatropha gossypiifolia L. in rats. Fitoterapia 74: 650-657.

Adesina SK 1982. Studies on some plants used as anticonvulsants in Amerindian and African tradicional medicine. Fitoterapia 53: 147-162.

Al-Zuhair H, El-Sayeh B, Ameen HA, Al-Shoora H 1996. Pharmacological studies of cardamom oil in animals. Pharmacol Res 34: 79-82.

Bolton TB 1979. Mechanisms of action of transmitters and other substances on smooth muscle. Physiol Rev 59: 606-718.

Calixto JB, Sant'ana AE 1987. Pharmacological analysis of the inhibitory effect of jatrophone, a diterpene isolated from Jatropha elliptica, on smooth and cardiac muscles. Phytother Res 1: 122.

Calixto JB, Sant'ana AE 1990. Evidence for the mechanism of the inhibitory action of jatrophone in the isolated rat uterine muscle. Gen Pharmacol 21: 117-122.

Caulfield MP 1993. Muscarinic Receptors-Characterization, coupling and function. Pharmacol Therapeut 58: 319379.

Coe FG, Anderson GJ 1996. Screening of medicinal plants used by the Garífuna of Eastern Nicaragua for bioactive compounds. J Ethnopharmacol 53: 29-50.

Corrêa MP 1984. Dicionário de plantas úteis do brasil e das exóticas cultivadas. vol. IV. Rio de Janeiro: Imprensa Nacional.

Das B, Anjani G 1999. Gossypidien, a lignan from stems of Jatropha gossypiifolia. Phytochemistry 51: 115-117.

Duarte DF, Sant'Ana AE, Calixto JB 1992. Analysis of the vasorelaxant action of jatrophone in the isolated aorta of the rat: influence of potassium channel blockers. Eur $J$ Pharmacol 215: 75-81.

Duke JA 1985. Handbook of medicinal herbs. Boca Raton: CRC Press.

Eglen RM, Hedge SS, Watson N 1996. Muscarinic receptor subtypes and smooth muscle function. Pharmacol Rev 48: 531-565.

Ghayur MN, Gilani AH, Khan A, Amor EC, Villasenor IM, Choudhary MI 2006. Presence of calcium antagonist activity explains the use of Syzygium samarangense in diarrhoea. Phytother Res 20: 49-52.

Gilani AU, Shah AJ, Ahmad M, Shaheen F 2006. Antispasmodic effect of Acorus calamus Linn. is mediated through calcium channel blockade. Phytother Res 20: 10801084.

Joly AB 1979. Botânica: introdução à taxonomia vegetal. 5 ed. São Paulo: Edit. Nacional.

Mariz SR, Araújo MST, Cerqueira GS, Araújo WC, Duarte JC, Diniz MFFM, Medeiros IA 2008. Avaliação histopatológica em ratos após tratamento agudo com o extrato etanólico de partes aéreas de Jatropha gossypiifolia L. Rev Bras Farmacogn 18: 213-216.

Mariz SR, Cerqueira GS, Araújo WC, Duarte JC, Melo AFM, Santos HB, Oliveira K, Diniz MFFM, Medeiros IA 2006. Estudo toxicológico agudo do extrato etanólico de partes aéreas de Jatropha gossypiifolia L. em ratos. Rev Bras Farmacogn 16: 372-378.

Mujumdar AM, Upadhye AS, Misar AV 2000. Studies on antidiarrhoeal activity of Jatropha curcus root extract in albino mice. J Ethnopharmacol 70: 183-187.

Ogbobe O, Akano V 1993. The physico-chemical properties of the seed and seed oil of Jatropha gossipifolia. Plant Foods Hum Nutr 43: 197-200.

Rao VS, Santos FA, Sobreira TT, Souza MF, Melo CL, Silveira ER 1997. Investigations on the gastroprotective and antidiarrhoeal properties of ternatin, a tetramethoxyflavone from Egletes viscosa. Planta Med 63: 146-149.

Shah AJ, Gowani SA, Zuberi AJ, Ghayur MN, Gilani AH 2010. Antidiarrhoeal and spasmolytic activities of the methanolic crude extract of Alstonia scholaris L. are mediated through calcium channel blockade. Phytother Res 24: 28-32.

Silva AM, Brum RL, Calixto JB 1995. The relaxant action of jatrophone in rat portal vein. A comparison with protein kinase C inhibitors. Life Sci 57: 863-871.

Subramanian SS, Nagarajan S, Sulochana N 1971. Flavonoids 
of the Leaves of Jatropha gossypiifolia. Phytochemistry 10: 1690

Van Rossum JM 1963. Cumulative dose-response curves. II. Technique for the making of dose-response curves in isolated organs and the evaluation of drug parameters. Arch Int Pharmacodyn Ther 143: 299-330.

Villar A, Paya M, Terencio MC 1986. Plants with antihypertensive action. Fitoterapia 57: 131-145.

Weiser M, Mutschler E, Lambrecht G 1997. Characterization of postjunctional muscarinic receptors mediating contraction in rat anococcygeus muscle. Naunyn Schmiedebergs Arch Pharmacol 356: 671-677.

\section{*Correspondence}

Selma do N. Silva

Laboratório de Pesquisa e Pós-graduação em Farmacologia, Departamento de Ciências Fisiológicas, Centro de Ciências Biológicas e da Saúde, Universidade Federal do Maranhão Avenida dos Portugueses s/n, 65085-580 São Luis-MA, Brazil selmansilva@ufma.br

Tel.: +55 9833018533

Fax: +55 9833018004 